\title{
Investigation of seasonal river-aquifer interactions in a tropical coastal area controlled by tidal sand ridges
}

\section{H. Calderon ${ }^{1,2}$ and S. Uhlenbrook $k^{1,3}$}

${ }^{1}$ UNESCO-IHE, Department of Water Science and Engineering, P.O. Box 3015, 2601 DA Delft, the Netherlands

${ }^{2}$ Nicaraguan Aquatic Resources Research Center at the National Autonomous University of Nicaragua (CIRA-UNAN), P.O. Box 4598, Managua, Nicaragua

${ }^{3}$ Delft University of Technology, Section of Water Resources, P.O. Box 5048, 2600 GA Delft, the Netherlands

Received: 24 July 2014 - Accepted: 7 August 2014 - Published: 19 August 2014

Correspondence to: H. Calderon (h.calderonpalma@unesco-ihe.org)

Published by Copernicus Publications on behalf of the European Geosciences Union.

\section{Investigation of river-aquifer \\ interactions in a tropical coastal area \\ H. Calderon and S. \\ Uhlenbrook}

\section{Title Page}

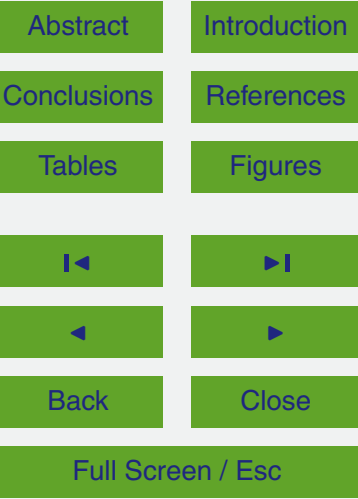

Printer-friendly Version

Interactive Discussion 


\section{Abstract}

Water exchanges between streams and aquifers influence the quantity and quality of water in both domains. Seasonal river-aquifer interactions were investigated in a tropical coastal area where tidal sand ridges control river discharge to the sea. The 5 study site is located in southwestern Nicaragua, dominated by humid tropical hydroclimatic conditions. The aquifer provides water to the rural town of Ostional. Connectivity between the river and the aquifer influences water quality and water availability for humans and for the downstream estuarine ecosystem. The effect of stream stage fluctuations on river-aquifer flows and pressure propagation in the adjacent aquifer investigated analyzing high temporal resolution hydraulic head data and applying a numerical model (HYDRUS 2-D). Tidal sand ridges at the river outlet control the flow direction between the river and the aquifer. Surface water accumulation caused by these features induces aquifer recharge from the river. Simulations show groundwater recharge up to $0.2 \mathrm{~m}^{3} \mathrm{~h}^{-1}$ per unit length of river cross section. Rupture of the flow between the river and the aquifer. Groundwater exfiltration reached $0.08 \mathrm{~m}^{3} \mathrm{~h}^{-1}$ immediately after the rupture of the sand ridges. Simulated bank storage flows are between $0.004-0.06 \mathrm{~m}^{3} \mathrm{~h}^{-1}$. These estimates are also supported by the narrow hysteresis loops between hydraulic heads and river stage. The aquifer behaves as confined, rapidly transmitting pressure changes caused by the river stage fluctuations. However, the pressure wave is attenuated with increasing distance from the river. Therefore, we concluded that a dynamic pressure wave is the mechanism responsible for the observed aquifer responses. Pressure variation observations and numerical groundwater modeling are useful to examine river-aquifer interactions and should be coupled in the
HESSD

11, 9759-9790, 2014

Investigation of

river-aquifer

interactions in a

tropical coastal area

H. Calderon and S.

Uhlenbrook

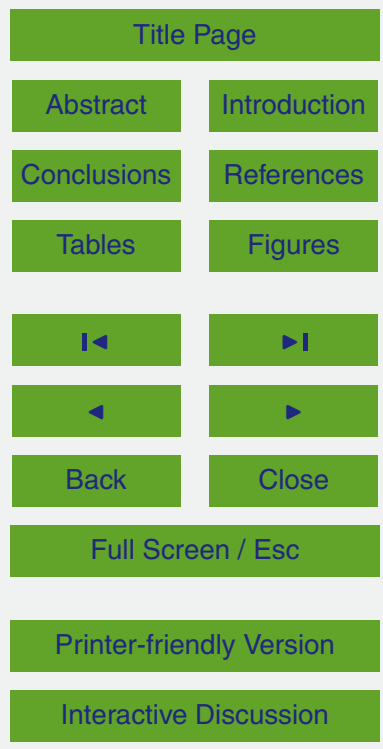




\section{Introduction}

Groundwater and surface water are both intrinsically related components of the hydrological cycle (Winter, 1998). The exchange of water between streams and aquifers influences the quality and quantity of water within both domains according to the fluxes and 5 water chemistry of the water moving through the streambed and the changes that occur at the groundwater-surface water interface (Ruehl et al., 2006). These interactions are essential for water supply, water quality and aquatic ecosystems (Sophocleous, 2002; Alley et al., 2006) and thus they are important for the sustainable management of water resources.

The movement of water between groundwater and surface water provides a major pathway for chemical transfer between terrestrial and aquatic systems (Winter, 1998). Hydraulic connections between groundwater and surface water also provide a conduit for the potential transport of contaminants (Oxtobee and Novakowski, 2002, 2003; Mendoza et al., 2008; Hoehn and Scholtis, 2011). These flows are controlled by the magnitude and distribution of hydraulic conductivities, the relation of stream stage to the adjacent water table and the geometry and position of the stream within the alluvial plain (Woessner, 2000). Kalbus et al. (2006) provides an extensive review of different methods to investigate groundwater-surface water interactions and states the need of a multi-scale approach which combines different methods to help quantify the fluxes estimates between rivers and aquifers. Temperature differences between surface water and groundwater are often used in combination with hydraulic gradients to investigate these interactions (Silliman and Booth, 1993; Conant, 2004; Anderson, 2005; Krause et al., 2012; Bartsch et al., 2014; Westhoff, 2007).

Piezometer transects across rivers are commonly used to monitor hydraulic gradiet al., 2014). However, hydraulic gradients between the river and the aquifer indicate only pressure distributions and quantification of fluxes requires knowledge of sediments hydraulic conductivities (Kaser et al., 2009). In lowland rivers, complex heterogeneities

HESSD

11, 9759-9790, 2014

Investigation of river-aquifer

interactions in a tropical coastal area

H. Calderon and S. Uhlenbrook

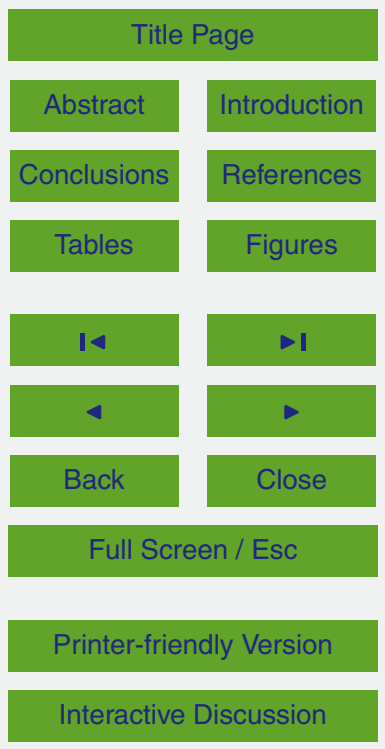


of the sediment and therefore the hydraulic conditions, pose a major challenge to use this approach (Krause et al., 2012).

Individual precipitation events may change the direction of water exchange between the surface and subsurface on a daily or even shorter time horizon, due to localized 5 recharge near the stream banks, flood peaks moving downstream or transpiration by river bank vegetation (Alley et al., 2006). Highly variable exchange fluxes are reported for intense precipitation seasons (Mendoza et al., 2008; Bartsch et al., 2014).

Bank storage occurs when stream water infiltrates in the adjacent aquifer during the rising stage of a flood. During the recession stage, the stored water moves back 10 into the stream. Bank storage may attenuate the flood peak (Pinder and Sauer, 1971) and increase the base time of the hydrograph (Chen and Chen, 2003). Release of stored water into the stream may also alter stream water quality (Squillace, 1996). Water table fluctuations may also occur through pressure exchange between surface water and groundwater without flow mixing (Wondzell and Gooseff, 2013). Pressure 15 wave propagation in floodplains has been analyzed by several authors using analytical solutions (Welch et al., 2013), principal component analysis of hydraulic head data (Lewandowski et al., 2009), cross-correlation of hydraulic head data, (Jung et al., 2004; Vidon, 2012; Cloutier et al., 2014), numerical modeling (Sophocleous, 1991; Chen and Chen, 2003) and combination of analytical and numerical methods (Barlow 20 et al., 2000).

The research site is located in the flat coastal catchment area of a tropical river; the surrounding aquifer provides water to the small rural town of Ostional, Nicaragua. Connectivity between the river and the aquifer influences water quality and water availability for humans and for the downstream estuarine ecosystem (Calderon et al., 2014).

25 Therefore, understanding the local recharge mechanism and discharge to the estuarine ecosystem are very important for water management of this area.

Examination of the interaction mechanisms between groundwater and surface water in tropical regions may differ from observations in temperate regions, based on the difference in rainfall intensity and seasonality (Bonell, 1993). Scarcity of detailed inves-
HESSD

11, 9759-9790, 2014

Investigation of

river-aquifer

interactions in a

tropical coastal area

H. Calderon and S.

Uhlenbrook

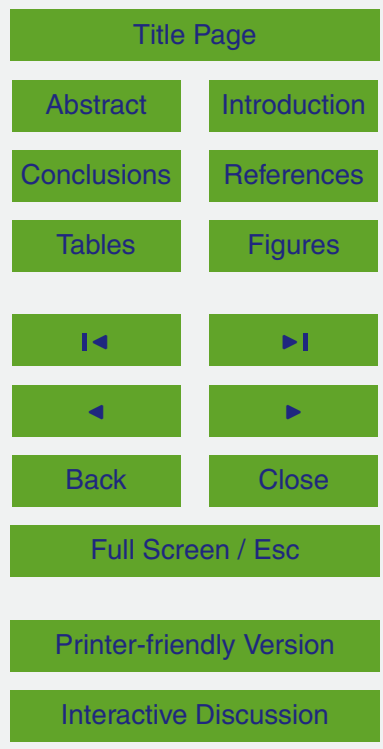


tigation in tropical regions leaves a gap in the scientific understanding of groundwatersurface water interactions. Transfer of commonly used hydrological methods from one hydro-climatic region may pose unexpected challenges. Therefore, our study is addressing the knowledge gap regarding river-aquifer interactions under tropical rainfall5 runoff conditions.

The objective of this work is to investigate the stream-aquifer interaction mechanisms and flow rates in a system where tidal sand ridges control the river discharge to the sea. The variability of the system during wet and dry conditions is also studied by: (i) analysing of hysteretic patterns of river stage and hydraulic heads, and (ii) 2-D 10 numerical modeling simulating pressure propagation in the groundwater system during river stage changes.

\section{Experimental site}

The study was carried out at the flat lower part of a coastal catchment located in the southwestern Pacific of Nicaragua. An experimental cross section (Fig. 1) at the 15 Ostional River was investigated for the period of March 2012-April 2013. The cross section is located next to the town with the same name. Population throughout the catchment is about 1500 people, most of which lives near the coast. Land use in the catchment is forest, subsistence agriculture and grazing. Agricultural is the main land use around the experimental site. Some patches of forest can also be found.

20 Local geology is composed of a $10-15 \mathrm{~m}$ thick clay-alluvial deposits unit on top of a fractured shale unit of unknown thickness. The top clay layer is discontinuous and relatively narrow $(3 \mathrm{~m})$. Hydraulic conductivity estimates for the upper unit range between $0.33 \mathrm{~m} \mathrm{~d}^{-1}$ and $6.7 \mathrm{~m} \mathrm{~d}^{-1}$ and the estimated value for the shale unit is $9.07 \mathrm{~m} \mathrm{~d}^{-1}$ (Calderon et al., 2014).

25 River channel geometry at the site is $18 \mathrm{~m}$ wide and streambed is composed of clay and silt. River banks are $1.8 \mathrm{~m}$ high on the West side and $1 \mathrm{~m}$ high on the East side. Both banks show a mixed matrix of alluvial materials and clay. River stage fluctuated
HESSD

$11,9759-9790,2014$

Investigation of

river-aquifer

interactions in a

tropical coastal area

H. Calderon and S.

Uhlenbrook

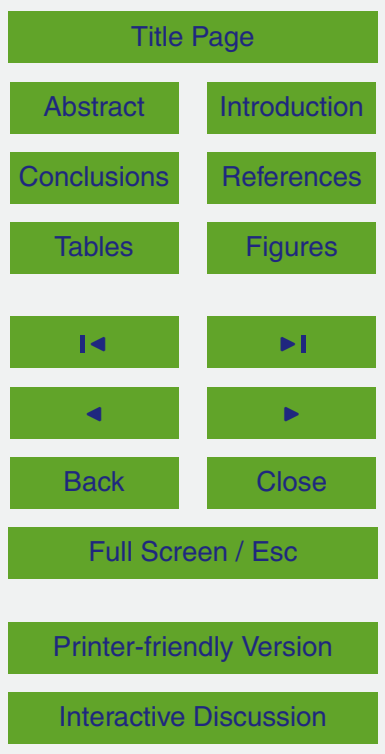


between $0.15 \mathrm{~m}$ and $0.85 \mathrm{~m}$ during the study period. River width varied between $1 \mathrm{~m}$ to bankfull, depending on precipitation events.

The geomorphology of coast in the study area is determined by strong waves and littoral drift, which produces sand ridges along the coast line. These geomorphologic 5 features control freshwater and seawater mixing and in/outflows of rivers and, consequently, the abiotic conditions of coastal ecosystems such as the mangrove forest just downstream of the study area (Calderon et al., 2014). Sand ridges are common on the Pacific Coast of Central America (Jimenez et al., 1999). Surface water accumulates in the estuary until the water levels overtop the ridges and rupture the ridges (Calderon 10 et al., 2014).

The rainy season spans from May to November. October is the rainiest month with an average accumulated precipitation during the study period of $618 \mathrm{~mm} \mathrm{month}^{-1}$ and a maximum of $1016 \mathrm{~mm}$ month $^{-1}$.

\section{Methods}

\section{3.1 Piezometric cross section}

Ten piezometers were installed at a cross section of the river (Fig. 1). Distance between piezometers is $25 \mathrm{~m}$. Piezometer depth increase away from the river on the East and West side. Shallowest piezometers are closest to the river banks. Drilling samples were correlated to produce a stratigraphic model (Calderon et al., 2014). Piezometers were completed at the end of February 2012 and divers were installed in early March 2012 and remained installed until April 2013.

Water table fluctuations and temperature were monitored continuously every $30 \mathrm{~min}$ in every piezometer and at the river, using Schlumberger mini divers, range $10 \mathrm{~m}$, DI501 (accuracy $\pm 0.005 \mathrm{~m}$ and $\pm 0.1^{\circ} \mathrm{C}$ ). Barometric compensation of the data was performed using atmospheric pressure data recorded at the same interval and for the same time period, using a mini baro diver, range $1.5 \mathrm{~m}$ (Schlumberger 50013, DI501).
HESSD

$11,9759-9790,2014$

Investigation of

river-aquifer

interactions in a

tropical coastal area

H. Calderon and S.

Uhlenbrook

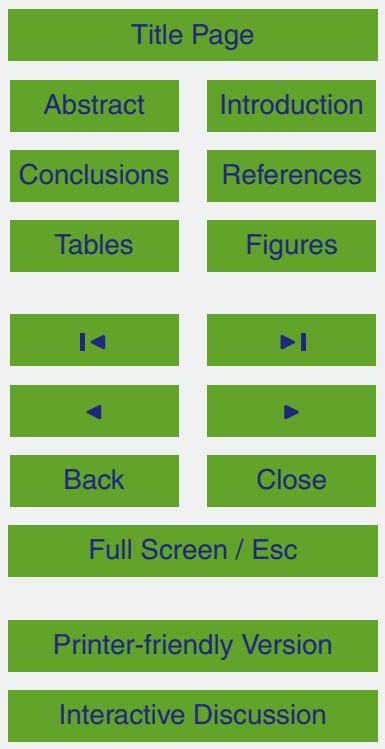


Elevations at the cross section were determined using a differential GPS with an average error of $\pm 0.009 \mathrm{~m}$. An electrical resistivity tomography (ERT) survey was performed at the cross section. The ABEM Lund Imaging System (Dahlin, 1996) was used with a Schlumberger array with a spacing of $5 \mathrm{~m}$. The ERT profile was $300 \mathrm{~m}$ long 5 and reached a depth of $60 \mathrm{~m}$. Data was inverted using RES2DINV (Loke and Barker, 2004). Resistivity ranges for each stratigraphic unit were identified through correlation with drilling samples. The ERT profile was then used to delineate the stratigraphy.

\subsection{Numerical model}

Pressure head changes at the piezometric cross section were simulated using HYDRUS 2-D (version 1.08). This finite element software numerically solves Richard's equation for variably saturated water flow and the convection-dispersion equation for heat and solute transport (Šimůnek et al., 2012). We decided to model only pressure heads since the temperature fluctuations in our study area are very small (less than $1^{\circ} \mathrm{C}$ ) to reliably reproduce them with limited knowledge of heat transport properties of 15 the streambed and aquifer materials.

The model domain is 160 wide and $30 \mathrm{~m}$ deep. The triangular mesh was automatically generated with an optimal size of $0.6 \mathrm{~m}$. The mesh was refined to $0.2 \mathrm{~m}$ at the boundaries of the model and around pressure head observation points (piezometers). The model time step was $30 \mathrm{~min}$ for the longer simulation periods and $0.2 \mathrm{~min}$ for the short simulation periods.

Boundary conditions were defined as variable pressure head at the West and East limits and the river bed. The top of the model is defined as an atmospheric boundary on the East side, which allows evaporation and infiltration. On the west side, the top of the model was defined as a variable seepage to atmospheric boundary condition. The seepage boundary condition allows groundwater flow when the water table rises near the model surface. When the water table is below the surface the boundary condition changes to atmospheric, allowing infiltration and evaporation.

\section{HESSD}

11, 9759-9790, 2014

Investigation of

river-aquifer

interactions in a

tropical coastal area

H. Calderon and S.

Uhlenbrook

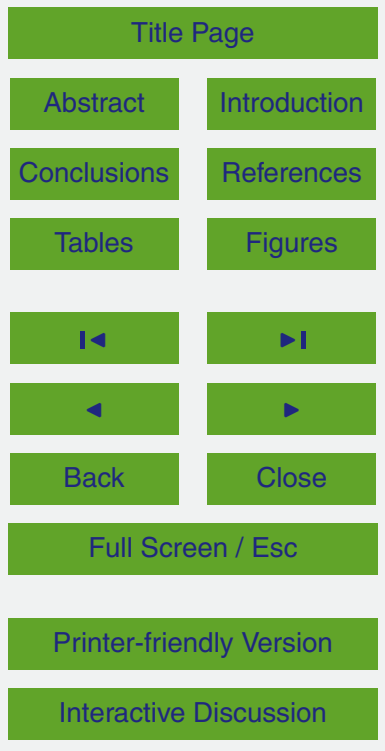


We assumed that there is no significant downward groundwater flow below the deepest piezometers, since the observed hydraulic gradient is upwards. Thus, the bottom of the model is defined as a no flow boundary. Initial conditions were defined by the observed pressure heads.

$5 \quad$ The stratigraphic model consists of three materials: clay, alluvium and shale (Fig. 1). The van Genuchten-Mualem soil hydraulic model was used to describe soil hydraulic parameters. Initial values of saturated hydraulic conductivity $\left(K_{\mathrm{s}}\right)$ for each material were defined based on slug test results (Calderon et al., 2014). Parameters of the van Genuchten-Mualem model were estimated using soil textures and the computer pro10 gram Rosetta (Schaap et al., 2001) which uses pedotransfer functions to predict van Genuchten's water retention parameters and saturated hydraulic conductivities. The selected soil textures are based on our initial estimates of $K_{\mathrm{s}}$. Rainfall and evaporation inputs were based on data from a monitoring station in the study area (Calderon and Uhlenbrook, 2014).

15 Since our model is 2-D, calculated flows are given in $\mathrm{L}^{2} \mathrm{~T}^{-1}$. Therefore, flows were multiplied per unit length $(1 \mathrm{~m})$ of the river cross section in order con convert them to $\mathrm{L}^{-3} \mathrm{~T}^{-1}$ units.

\subsection{Model calibration}

HYDRUS implements the Marquardt-Levenberg parameter estimation technique. The method combines Newton's and steepest descend methods to generate confidence intervals for $K_{\mathrm{s}}$ (Šimůnek et al., 2012). The optimization process is based on the minimization of the objective function which states the difference between observed and estimated values. The objective function defined by Šimůnek et al. (1998) accounts for deviations between measured and calculated space-time pressure heads and dif25 ferences between measured and calculated $K_{\mathrm{s}}$ (Šimůnek et al., 2012). The objective function is defined as:

\section{HESSD}

11, 9759-9790, 2014

Investigation of

river-aquifer

interactions in a

tropical coastal area

H. Calderon and S.

Uhlenbrook

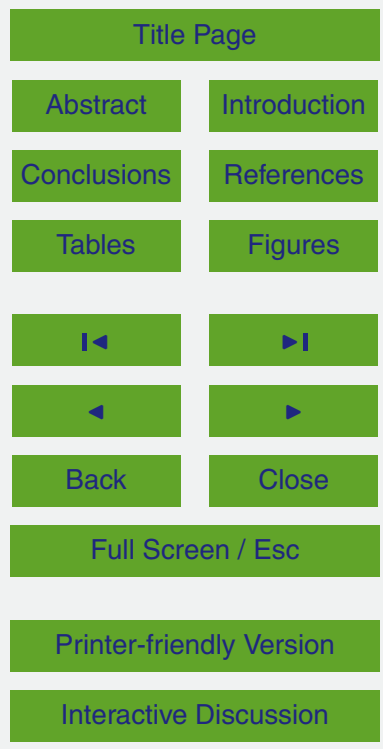




$$
\begin{aligned}
\phi(b, p, q) & =\sum_{j=1}^{m_{q}} v_{j} \sum_{i=1}^{n_{q j}} w_{i, j}\left[q_{j}^{*}\left(x, t_{i}\right)-q_{j}\left(x, t_{i}, b\right)\right]^{2} \\
& +\sum_{j=1}^{m_{p}} \bar{v}_{j} \sum_{i=1}^{n_{p j}} \bar{w}_{i, j}\left[p_{j}^{*}\left(\theta_{i}\right)-p_{j}\left(\theta_{i}, b\right)\right]^{2}+\sum_{j=1}^{n_{b}} \hat{v}_{j}\left[b_{j}^{*}-b_{j}\right]^{2}
\end{aligned}
$$

where the first term on the right hand side represents the deviation between measured 5 and calculated space-time variables, $m_{q}$ is the number of different sets of measurements and $n_{p j}$ is the number of measurements in a particular set. $q_{i}^{*}$ represents specific measurements at time $t_{i}$ for the $j$ th measurement at a location $x(r, z), q_{j}\left(x, t_{i}, b\right)$ are the model predictions for the vector of optimized parameters $b\left(K_{\mathrm{s}}\right), v_{i}$ and $w_{i, j}$ are the weights associated with a particular measurement set or point, respectively. The second term is the difference between independently measured and predicted soil hydraulic properties. The terms $m_{p}, n_{p j}, p_{j}^{*}\left(\theta_{i}\right), p_{j}\left(\theta_{i, b}\right), v_{j}$ and $w_{i, j}$ have similar meaning than in the first term, but for the soil hydraulic properties. The last term is a penalty function for deviations between prior knowledge of the soil hydraulic parameters $b_{j}^{*}$ and their final estimates $b_{j}, n_{b}$ is the number of parameters with prior knowledge and $15 \hat{v}_{j}$ represents pre-assigned weights.

The model was calibrated for the dry period of 1 December 2012-10 March 2013 by inversely calculating $K_{\mathrm{s}}$. The $K_{\mathrm{s}}$ values of the three materials were iteratively adjusted with the objective function until the simulated pressure heads approximated the observed values. The range of $K_{\mathrm{s}}$ values was constrained by the estimations from slug tests. A set of 506 pressure head $\left(h_{p}\right)$ observations were used to minimize the objective function to 0.012 . The $R^{2}$ between predicted and observed values was 0.99 . Optimization parameters are presented in Table 1 along with soil water retention parameters estimated by the Rosetta software. The same model was used to simulate a second set of pressure head observations from the rainy period of 1-30 October 2012.
HESSD

11, 9759-9790, 2014

Investigation of

river-aquifer

interactions in a

tropical coastal area

H. Calderon and S.

Uhlenbrook

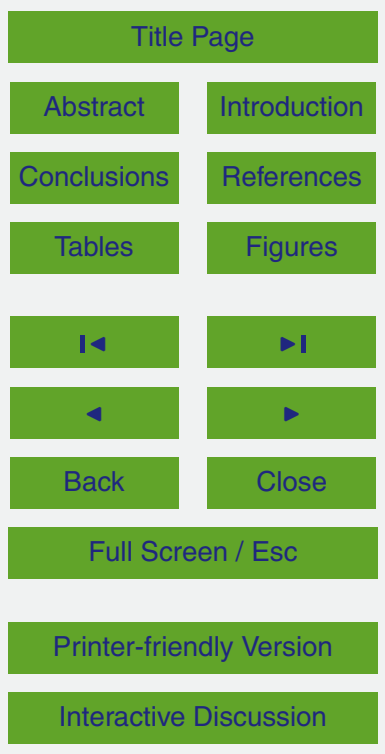




\subsection{River stage change simulations}

Changes in river stage were simulated for the rainiest period within the time span of the study, from 1 to 30 October 2012, in order to look into short-terms changes in the river-aquifer interactions. Additionally, the effect of larger river stage fluctuations were 5 investigated through modelling. Since 2012 was a relatively dry year compared to 2011 and 2010 (Calderon and Uhlenbrook, 2014) no bankfull events were observed. Thus, a hypothetical bankfull event was recreated based on the highest precipitation records between 2010 and 2012. We selected a rainfall event from 19 October 2011 which had an accumulated precipitation of $100 \mathrm{~mm}$ during $5 \mathrm{~h}$. Unfortunately, no river stage data was available before 2012. Therefore, river stage was inversely estimated using a rating curve from a rainfall event occurred in 2012 with an $R^{2}$ of $0.84(n=21)$.

River discharge was estimated assuming that all precipitation in excess of soil infiltration capacity generates surface runoff (Fetter, 2001). We did not consider depression storage. The contributing area was assumed to be the alluvial valley of $1 \mathrm{~km}^{2}$, since for the simulated event no precipitation was observed in the upstream catchment area (Calderon and Uhlenbrook, 2014). Infiltration capacity was estimated in $10 \mathrm{~mm} \mathrm{~h}^{-1}$ (Calderon and Uhlenbrook, 2014). Two sets of initial conditions were used for the simulation of the hypothetical event: dry and wet period. Thus, the influence of the initial water table could be also analyzed. They were defined based on the hydraulic pressure distribution results from the calibration period.

\section{Results}

\subsection{Hydraulic head fluctuations and sand ridges}

Daily precipitation, river stage and piezometer hydraulic heads are presented in Fig. 2. Daily precipitation (Fig. 2a) was usually below $25 \mathrm{~mm} \mathrm{~d}^{-1}$, except in October when the 25 highest value reached $140 \mathrm{~mm} \mathrm{~d}^{-1}$ (25 October).
HESSD

11, 9759-9790, 2014

Investigation of

river-aquifer

interactions in a

tropical coastal area

H. Calderon and S.

Uhlenbrook

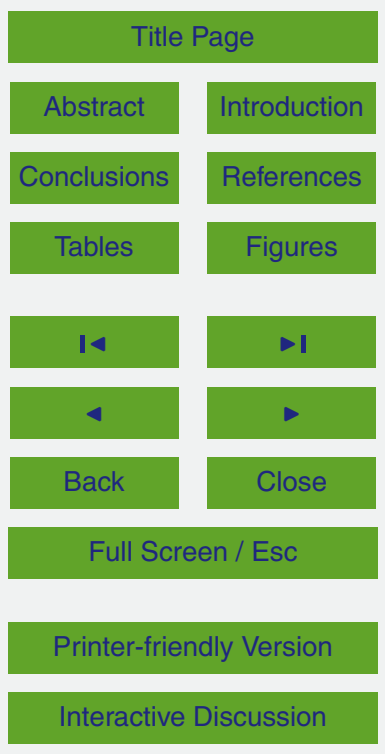


River stage and hydraulic head fluctuations (Fig. 2b) show a synchronous pattern throughout the study period, indicating a strong hydraulic connection between the river and the adjacent aquifer. During the first two months of monitoring, the river course was temporarily deviated to construct a bridge. This caused the irregular behavior observed during April-June 2012.

A sustained increase in hydraulic heads was observed from April to June 2012, despite the lack of precipitation. The river stage also increased during this period. The increases in both surface and groundwater levels are explained by groundwater discharge coming from the upper catchment. The presence of sand ridges prevents sur10 face water discharge to the ocean, causing surface water accumulation and aquifer recharge from the river. Sudden drops in river stage were caused by rupture of the beach ridges (Calderon et al., 2014). Small precipitation events caused peaks in river stage and groundwater levels (i.e. end of June 2012).

Two large river stage increases $(0.6 \mathrm{~m}$ each) and a smaller one $(0.3 \mathrm{~m})$ were ob15 served during October 2012 (Fig. 2c). The first occurred between the 1 and 6 October. However, the rising part of this peak is missing due to technical problems. The second peak occurred between the 14 and 20 October. The third peak occurred between the 21 and 31 October. River bank piezometers experienced a hydraulic head increase equal to the increase in river stage for peaks 1 and 2. Piezometers located farther from the river bank suffered an increase of $0.5 \mathrm{~m}$. In the case of peak 3 , hydraulic heads on the west side of the river increased $0.2 \mathrm{~m}$ and only $0.1 \mathrm{~m}$ on the east side.

Local precipitation in Ostional was exceptionally high, $700 \mathrm{~mm} \mathrm{month}^{-1}$ for October 2012. Whereas upstream rain stations recorded $263 \mathrm{~mm} \mathrm{month}^{-1}$ and $289 \mathrm{~mm} \mathrm{month}^{-1}$ (Calderon and Uhlenbrook, 2014). Accumulated precipitation from 6 to 19 October was $322 \mathrm{~mm}$ in Ostional, which caused the second river stage peak. However, the amplitude of this peak was also enhanced by the beach sand ridges blocking the river outlet to the ocean. The precipitation event during the night of 19 October $2012\left(134 \mathrm{~mm} \mathrm{~d}^{-1}\right)$ caused excess of stored water which induced the ruptured of the beach ridges. The system released the stored water on the 20 October between 09:00 LT and 17:00 LT.

HESSD

$11,9759-9790,2014$

Investigation of river-aquifer

interactions in a tropical coastal area

H. Calderon and S. Uhlenbrook
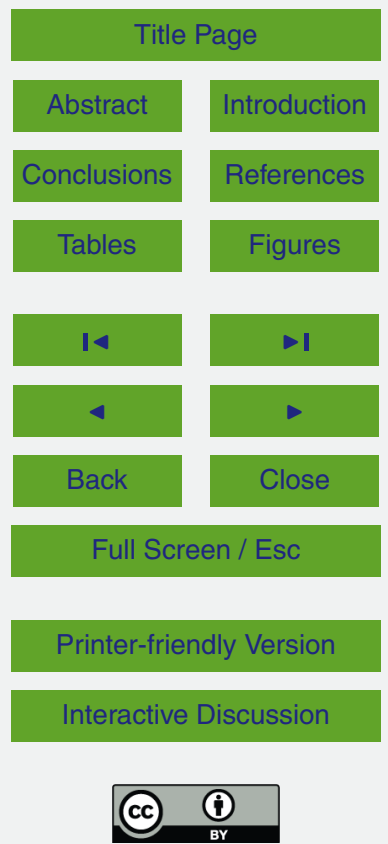
The third peak was caused by the accumulated precipitation between the 20 and 26 October which amounted to $361 \mathrm{~mm}$.

\subsection{Surface water and groundwater temperature fluctuations}

Temperature fluctuations for air, surface water and groundwater were monitored during 5 temperature range was higher, between $39.7^{\circ} \mathrm{C}$ and $23.1^{\circ} \mathrm{C}$. River water was warmer because river depth was shallow and under direct exposure to sunlight.

Groundwater temperatures for the shallow piezometers were between $28^{\circ} \mathrm{C}$ and $31^{\circ} \mathrm{C}$ between April and June 2012 (dry season). As the river temperature dropped in early June due to precipitation, so did the temperatures in these piezometers. On the East side, groundwater temperature stayed stable at around $28^{\circ} \mathrm{C}$. Groundwater temperature on the West side gradually decreased between mid-June and mid October 2012 (rainy period) to values between $28^{\circ} \mathrm{C}$ and $28.5^{\circ} \mathrm{C}$. The deepest piezometers located farthest from the river (P3W and P3E) show stable temperatures. P3E shows 15 temperature at around $29^{\circ} \mathrm{C}$. Only during the peak of the rainy season a drop of $0.3^{\circ} \mathrm{C}$ was observed. Highest temperature in P3W was $29.5^{\circ} \mathrm{C}$, in mid-June 2012. During mid-October 2012 the temperature slowly decreased to $28.6^{\circ} \mathrm{C}$ and stayed stable until the end of the study.

\subsection{Hysteretic patterns in hydraulic heads}

20 Hysteresis patterns were analyzed for the periods with and without the presence of sand ridges. Daily average hydraulic heads were plotted against river stage (Fig. 3) for the second and third river stage peaks. In the case of the second peak all hysteretic patterns are counterclockwise. The counterclockwise pattern indicates lower hydraulic heads during the rising limb and higher heads during the falling limb. Thus, demonstrating bank storage. However, the hysteresis loops are narrow. This indicates that the changes in groundwater levels between the rising and falling limb of the hydrograph are
HESSD

11, 9759-9790, 2014

Investigation of

river-aquifer

interactions in a

tropical coastal area

H. Calderon and S.

Uhlenbrook

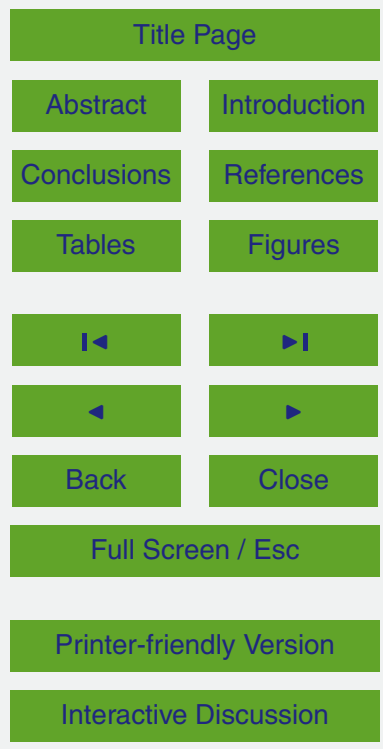


small, only about $0.1 \mathrm{~m}$. For the third peak the loops are not completely closed because the river stage and hydraulic heads were higher at the beginning of this period due to the influence of the second peak.

During both periods we observed higher hydraulic heads on the west side of the river.

5 Also the heads in piezometers located closest to the river indicate a downward gradient from the shallowest piezometers (P1W1 and P1E1) towards the deeper piezometers (P1W and P1E). However, an upward gradient is observed between the piezometers located farthest from the river (P3W-P3W1 and P3E-P3E1). However, we do not show results from $\mathrm{P} 3 \mathrm{E} 1$ because during the rainy period this piezometer reacted immediately 10 to precipitation events, probably because of precipitation shortcutting around the base of the piezometer.

\subsection{Statistical evaluation of model calibration}

Statistical analysis of the model performance is summarized in Table 2. The mean absolute error (MAE), correlation coefficients $\left(R^{2}\right)$, the root mean square errors (RMSE) are presented. Mean absolute error varies between $0.07 \mathrm{~m}$ and $0.22 \mathrm{~m}$ for the dry period; and between $0.06 \mathrm{~m}$ and $1.3 \mathrm{~m}$ for the rainy period. Correlation coefficients vary between 0.88 and 0.99 . Highest RMSE is 0.3 for the dry period and 1.06 for the rainy period. The $R^{2}$ and RMSE values reflect the fact that the model is capable of reproducing the pressure head dynamics for both periods. The MAE indicates the difference between observed and simulated pressure heads.

\subsection{Simulation of river stage changes}

\subsubsection{Rainy period}

The rainy period of October 2012 was simulated. Pressure head dynamics in all piezometers were well simulated, except in P3W1 and P3E, probably because of local 25 heterogeneities not captured by the model. Results for the shallowest piezometers are

\section{HESSD}

$11,9759-9790,2014$

Investigation of

river-aquifer

interactions in a

tropical coastal area

H. Calderon and S.

Uhlenbrook

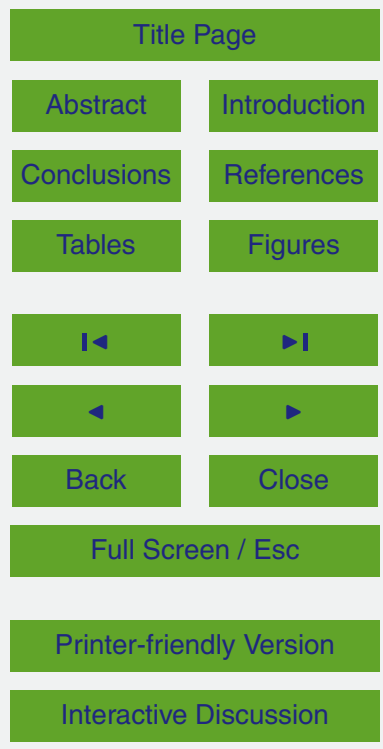


shown in Fig. 4. Model performance on the west side was better. Average of the MAE for west piezometers was $0.55 \mathrm{~m}$, and for East piezometers was $0.66 \mathrm{~m}$.

The synchronous response in all piezometers to river stage changes was examined by looking at groundwater flow velocities between the river and the piezometer loca5 tions. Average linear velocity estimated for river bank piezometers assuming an effective porosity of $0.3(-)$ yields values of $3 \mathrm{~m} \mathrm{~d}^{-1}$; for the other piezometers estimates are between $0.3 \mathrm{~m} \mathrm{~d}^{-1}$ and $0.4 \mathrm{~m} \mathrm{~d}^{-1}$. The numerical model estimated a maximum groundwater effective velocity of approximately $0.3 \mathrm{~m} \mathrm{~d}^{-1}$. These velocities cannot explain the timing of the water table response. It would take between $7 \mathrm{~h}$ (for riverbank piezome10 ters) and 100 days (for the farthest piezometers), for groundwater recharge from the river to reach them mainly due to the low slope and the given hydraulic conductivities. Therefore, we conclude that the change in pressure heads is driven by a nearly instantaneous pressure wave from the river towards the aquifer. This wave is, however, attenuated by up to $50 \%$ when it reaches the piezometers located farthest from the river (horizontal distance $50 \mathrm{~m}$ ).

The peak groundwater recharge was similar for 6 and 20 October, approximately $0.08 \mathrm{~m}^{3} 30 \mathrm{~min}^{-1}$ (Fig. 5). In both cases river stage increase was $0.6 \mathrm{~m}$ and the sudden change in flow direction was caused by rupture of sand ridges. Maximum groundwater exfiltration occurred immediately after the rupture of sand ridges and it reached $0.04 \mathrm{~m}^{3}$ $30 \mathrm{~min}^{-1}$. Beginning on 21 October groundwater recharge has a different dynamics. Recharge reached approximately $0.02 \mathrm{~m}^{3} 30 \mathrm{~min}^{-1}$. The change in flow direction was gradual. This is because the river was flowing freely into the ocean after the rupture of sand ridges.

After 26 October, without sand ridges present and without precipitation, groundwater exfiltration reached approximately $0.02 \mathrm{~m}^{3} 30 \mathrm{~min}^{-1}$. Nevertheless, it remained near that value for about 5 days (Fig. 5). The difference in the duration and magnitude of groundwater exfiltration with and without sand ridges present, indicate the large control of these geomorphologic features on groundwater-surface water interactions.

\section{HESSD}

11, 9759-9790, 2014

Investigation of

river-aquifer

interactions in a

tropical coastal area

H. Calderon and S.

Uhlenbrook

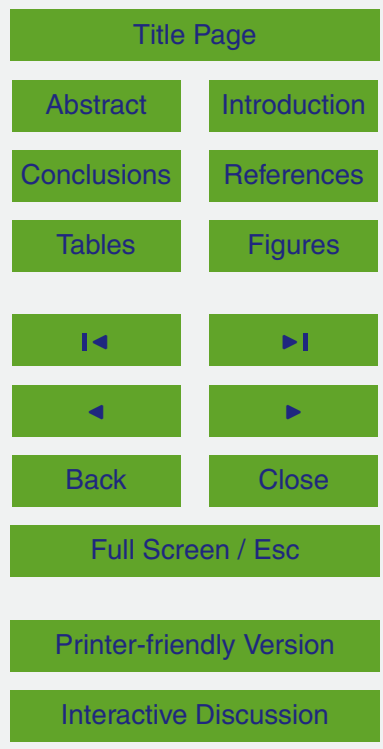


Small periodic shifts are observed in the flow direction. They have a periodicity of about $24 \mathrm{~h}$ and given the lack of precipitation, they are attributed to high tide influence on the river stage. Mixed semidiurnal tides were observed during this period, with two high tides of different amplitude during $24 \mathrm{~h}$. However, only the larger amplitude tide 5 had an effect on the streambed flow.

\subsubsection{Hypothetical river stage peak}

The simulated flows between the river and the aquifer for both sets of initial conditions are presented in Fig. 6. For dry period initial conditions, groundwater recharge occurs during the entire simulation period (Fig. 6a). Groundwater recharge is higher during o peak river stage (at $210 \mathrm{~min}$ ) and reaches $0.1 \mathrm{~m}^{3} 30 \mathrm{~min}^{-1}$. Analysis of flows across the river banks shows groundwater exfiltration after peak river discharge (Fig. 6b). The West bank continues to exfiltrate groundwater after the peak, reaching $0.002 \mathrm{~m}^{3}$ $30 \mathrm{~min}^{-1}$. The East bank exfiltrated groundwater only during peak river stage, reaching $0.005 \mathrm{~m}^{3} 30 \mathrm{~min}^{-1}$.

15 Wet initial conditions produce a different pattern in flow direction. Groundwater recharge occurs only during peak river stage and reaches $0.05 \mathrm{~m}^{3} 30 \mathrm{~min}^{-1}$ (Fig. 6c). Groundwater exfiltration starts before the river stage peak. Exfiltration is caused by an increase in groundwater levels due to recharge by precipitation. Exfiltration on the West bank reached $0.007 \mathrm{~m}^{3} 30 \mathrm{~min}^{-1}$ and on the East bank it reached $0.026 \mathrm{~m}^{3} 30 \mathrm{~min}^{-1}$ 20 (Fig. 6d).

\section{Discussion}

\subsection{Effect of sand ridges on groundwater-surface water flows}

Surface water accumulation due to the presence of sand ridges in the river mouth controls the flow direction between the river and the aquifer (Fig. 7). The observed

fluctuations in river stage and hydraulic heads and the river-aquifer flows estimated
HESSD

$11,9759-9790,2014$

Investigation of

river-aquifer

interactions in a

tropical coastal area

H. Calderon and S.

Uhlenbrook

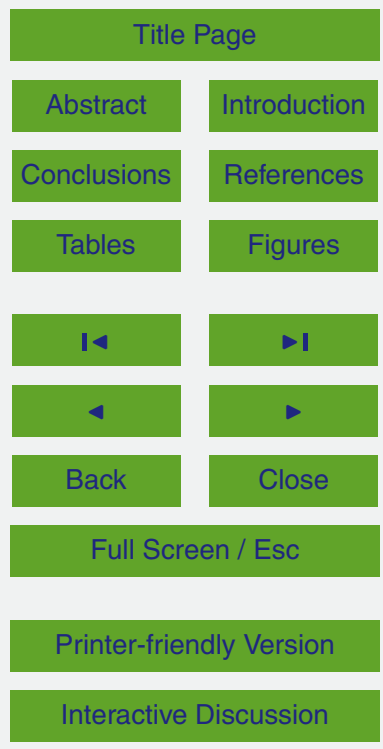


by the model, indicate that the presence of sand ridges causes groundwater recharge. The largest observed river stage increments $(0.6 \mathrm{~m})$ caused an approximate increase of $0.5 \mathrm{~m}$ in hydraulic heads. Simulations also indicate groundwater recharge up to $0.08 \mathrm{~m}^{3}$ $30 \mathrm{~min}^{-1}$ from the stream during these periods. The rupture of sand ridges on $20 \mathrm{Oc}$ 5 tober 2012 caused a sudden release of surface water into the ocean. This release also caused a reversal in the direction of the river-aquifer flow direction, allowing groundwater exfiltration of up to $0.04 \mathrm{~m}^{3} 30 \mathrm{~min}^{-1}$.

\subsection{Bank storage}

Hysteresis loops of river-stage and hydraulic heads show a counterclockwise pattern, indicating bank storage. However, the loops are narrow which indicates that relative changes in hydraulic head between the rising and falling limbs are small. Hydraulic head response to river stage changes is fast. In the case of the second peak in river stage, heads returned to their initial values $10 \mathrm{~h}$ after the rupture of the sand ridges. $A$ fast response is also observed for individual events occurred after the rupture of sand ridges. The first event had a river stage peak of $0.3 \mathrm{~m}$ and stored water was released within $10 \mathrm{~h}$ after the peak. The second event had a river stage peak of $0.16 \mathrm{~m}$ and stored water was released within $5 \mathrm{~h}$ after the peak.

\subsection{Effects of river stage changes on groundwater recharge}

Simulations indicate that most stream infiltration occurs through the river bed by vertical flow. Hydraulic gradients across river banks shift with peak river stage. The effect is shorter in duration in the East river bank. The flow across the river banks are small $\left(0.04 \mathrm{~m}^{3} 30 \mathrm{~min}^{-1}\right.$ to $\left.0.2 \mathrm{~m}^{3} 30 \mathrm{~min}^{-1}\right)$ which supports the analysis of the bank storage through hysteresis loops. The amount of stored water is small and it is released within a short time period (10 h) Bartsch et al. (2014) found frequent river-aquifer flow reversals

\section{HESSD}

$11,9759-9790,2014$

Investigation of river-aquifer

interactions in a

tropical coastal area

H. Calderon and S.

Uhlenbrook

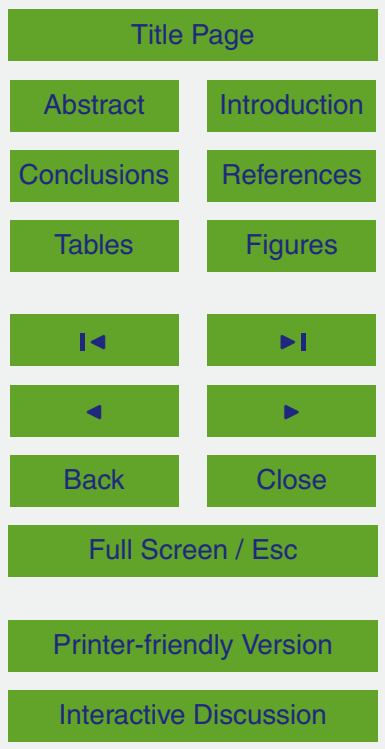


gradients are caused by intense precipitation events which caused increases in river stage. In our case river stage increases are controlled by sand ridges.

Observed and simulated pressure heads show a synchronous behavior with river stage. This response cannot be explained by Darcian flow. Average linear groundwater 5 flow velocities between the river and piezometers are estimated between $0.3 \mathrm{~m} \mathrm{~d}^{-1}$ and $3 \mathrm{~m} \mathrm{~d}^{-1}$. The estimated times for a flood wave to arrive to the piezometers nearest to the river is $7 \mathrm{~h}$ and to the piezometers farthest away from the river is 100 days. Therefore, we infer that the changes in pressure heads are driven by a nearly instantaneous dynamic pressure wave from the river towards the aquifer. This wave is attenuated by 10 up to $50 \%$ when it reaches the piezometers located farthest from the river. The fast propagation of the pressure wave may be explained by the clay unit in the aquifer. Sophocleous (1991) found that the Grand Bend Prairie aquifer in Kansas, behaved as confined because of the widespread shallow and thin clay layers within the aquifer. The aquifer had low storativity but high transmissivity. Thus, pressure waves from the 15 streams travel fast and to great distances (tens of kilometers). The pressure waved caused by stream stage changes was explained as fluid molecules transmitting pressure between each other, with very small spatial displacement (Sophocleous, 1991).

Following this line, Jung et al. (2004) explained the water table response in a floodplain to river stage increases through the kinematic wave mechanism, since the synchronous response could not be explain by the much lower Darcian velocities. Cloutier et al. (2014) also found that Darcian flow was not sufficient to cause flood wave propagation from a river into the adjacent aquifer in the floodplain. Thus, they proposed a dynamic wave mechanism as explanation for the water table response since the hydraulic head fluctuations were not conservative in time and space. The difference between both mechanisms is that the kinematic wave is non-dispersive and nondiffusive, whereas the dynamic wave is dispersive and diffusive (Cloutier et al., 2014). Vidon (2012) found that Darcy's velocities were 2 to 3 order of magnitude too small to account for the water table response to river stage increases. Also, they showed that infiltration from precipitation was not responsible for the fast water table response, since

\section{HESSD}

$11,9759-9790,2014$

Investigation of river-aquifer

interactions in a

tropical coastal area

H. Calderon and S.

Uhlenbrook

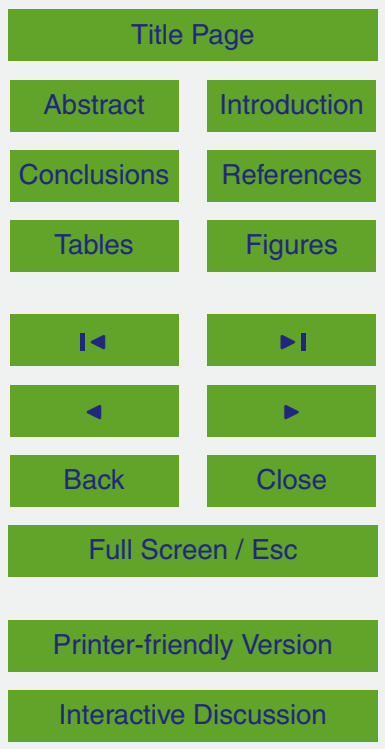


electrical conductivity of riparian groundwater remained stable instead of decreasing. Therefore, they explained the rapid water table rise by means of a kinematic wave processes. Lewandowski et al. (2009) also found a dynamic wave mechanism in the pressure propagation between a stream and an aquifer. They found that Darcy's veloci5 ties were 100 times slower that the pressure wave propagation in an alluvial unconfined aquifer. They also found dampening of the pressure wave with distance from the river. In our case, the attenuation of the pressure wave with distance from the river indicates that the mechanism for propagation is a dynamic wave.

\section{Conclusions}

10 Tidal sand ridges at the river outlet control the flow direction between the river and the aquifer. Surface water accumulation caused by these features at the river outlet induce aquifer recharge from the river. The simulations show that the larger river stage increases caused by sand ridges increase groundwater recharge significantly. Rupture of the sand ridges (by overtopping and erosion) causes release of the stored surface water and a sudden shift in the direction of flow between the river and the aquifer. The difference in the duration and magnitude of groundwater exfiltration with and without sand ridges present, indicate the large control of these geomorphologic features on ground water-surface water flow exchange.

Bank storage occurs during stream stage increases. However, the volume of stored 20

water is small $\left(0.004 \mathrm{~m}^{3} \mathrm{~h}^{-1}\right.$ to $\left.0.06 \mathrm{~m}^{3} \mathrm{~h}^{-1}\right)$. Stored water is quickly released back into the stream after the peak river stage. The hydraulic gradients across the river banks show shifts during flood events. During dry conditions a flood event causes a reversal in the hydraulic gradient. After peak river stage, river banks release water into the stream, although in very small amounts. During wet conditions, river bank flow becomes more significant. However, under both scenarios, vertical streambed infiltration remains the most important component of aquifer recharge during stream stage peaks.

Investigation of river-aquifer

interactions in a tropical coastal area

H. Calderon and S.

Uhlenbrook

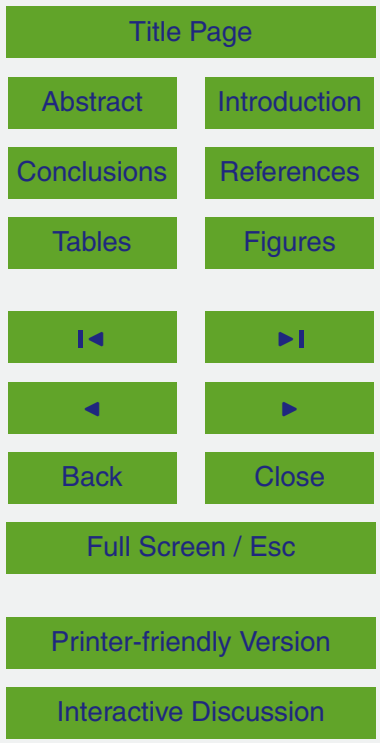


The synchronous response of the water table to river stage fluctuations cannot be explained solely based on linear average velocities. Estimated travel times from the river to the observation points are much longer than those observed. The nearly instantaneous response of the aquifer to the pressure wave caused by the stream stage 5 increased is explained by the presence of the discontinuous clay layer on top of the aquifer.

The aquifer behaves as confined, rapidly transmitting pressure changes caused by the river stage increase. The pressure wave is attenuated with increasing distance from the river. Therefore, we propose a dynamic pressure wave as the mechanism respon10 sible for the observed aquifer response; as opposed to the kinematic wave mechanism, which would not be attenuated with time nor distance.

Pressure variation observations in combination with numerical surface water/groundwater modeling are useful to examine river-aquifer interaction processes in tropical climates with highly variable hydrologic conditions. In the future, these observa15 tions should be coupled with chemical data to improve process understanding through quantification of fluxes and modeling. Although coupling of hydraulic and temperature observations is an effective approach in temperate climates, the observed small differences between surface and groundwater temperature in this tropical hydro-climatic region, precludes the effective use of this type of data.

20 Acknowledgements. The authors thank the National Autonomous University of Nicaragua (UNAN-Managua) and the Nicaraguan Aquatic Resources Research Center (CIRA-UNAN) which granted the first author a study permit to conduct her PhD research. Thom Bogaard (Delft University of Technology) is also acknowledged for providing access to the HYDRUS 2-D software. Thanks to J. Šimunnek for his input on the HYDRUS model. Many thanks to Gerald A. Corzo (UNESCO-IHE) for his help during the diver data processing and valuable com-

ments on optimization and simulation results. Funding for this work was generously provided by the Faculty for the Future program (http:www.facultyforthefuture.net) and the Netherlands fellowship program from Nuffic (http:www.nuffic.nl).

HESSD

$11,9759-9790,2014$

Investigation of

river-aquifer

interactions in a

tropical coastal area

H. Calderon and S.

Uhlenbrook

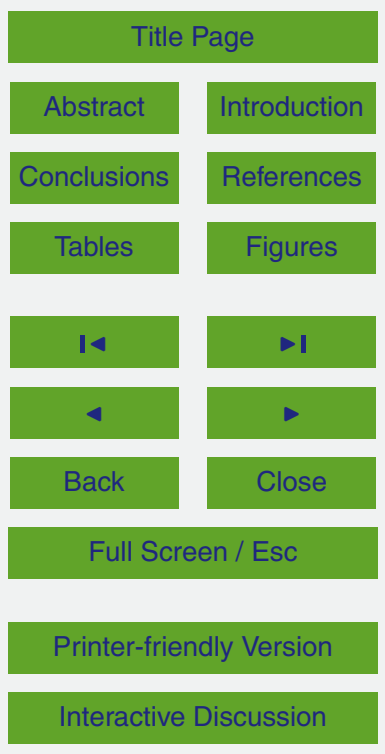

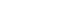




\section{References}

Alley, W. M., La Baugh, J. W., and Reilly, T. E.: Groundwater as an Element in the Hydrological Cycle, in: Encyclopedia of Hydrological Sciences, John Wiley \& Sons, Ltd, 1-13, 2006.

Anderson, M. P.: Heat as a Ground Water Tracer, Ground Water, 43, 951-968, doi:10.1111/j.1745-6584.2005.00052.x, 2005.

Barlow, P. M., DeSimone, L. A., and Moench, A. F.: Aquifer response to stream-stage and recharge variations, II, Convolution method and applications, J. Hydrol., 230, 211-229, doi:10.1016/S0022-1694(00)00176-1, 2000.

Bartsch, S., Frei, S., Ruidisch, M., Shope, C. L., Peiffer, S., Kim, B., and Fleckenstein, J. H.: River-aquifer exchange fluxes under monsoonal climate conditions, J. Hydrol., 509, 601-614, doi:10.1016/j.jhydrol.2013.12.005, 2014.

Bonell, M.: Progress in the understanding of runoff generation dynamics in forests, J. Hydrol., 150, 217-275, doi:10.1016/0022-1694(93)90112-M, 1993.

Calderon, H. and Uhlenbrook, S.: Characterising the climatic water balance dynamics and different runoff components in a poorly gauged tropical forested catchment, Nicaragua, Hydrological Sciences Journal, in press, 2014.

Calderon, H., Weeda, R., and Uhlenbrook, S.: Hydrological and Geomorphological Controls on the Water Balance Components of a Mangrove Forest During the Dry Season in the Pacific Coast of Nicaragua, Wetlands, 1-13, doi:10.1007/s13157-014-0534-1, 2014.

Cloutier, C. A., Buffin-Bélanger, T., and Larocque, M.: Controls of groundwater floodwave propagation in a gravelly floodplain, J. Hydrol., 511, 423-431, doi:10.1016/j.jhydrol.2014.02.014, 2014.

Conant, B.: Delineating and Quantifying Ground Water Discharge Zones Using Streambed Temperatures, Ground Water, 42, 243-257, doi:10.1111/j.1745-6584.2004.tb02671.x, 2004.

Chen, $\mathrm{X}$. and Chen, X.: Stream water infiltration, bank storage, and storage zone changes due to stream-stage fluctuations, J. Hydrol., 280, 246-264, doi:10.1016/S0022-1694(03)002324, 2003.

Dahlin, T.: 2-D resistivity surveying for environmental and engineering applications, First Break, 14, 275-283, 1996.

30 Fetter, C.: Applied hydrogeology, 4th Ed., Prentice Hall Upper Saddle River, New Jersey, 598 pp., 2001.
HESSD

11, 9759-9790, 2014

Investigation of

river-aquifer

interactions in a

tropical coastal area

H. Calderon and S.

Uhlenbrook

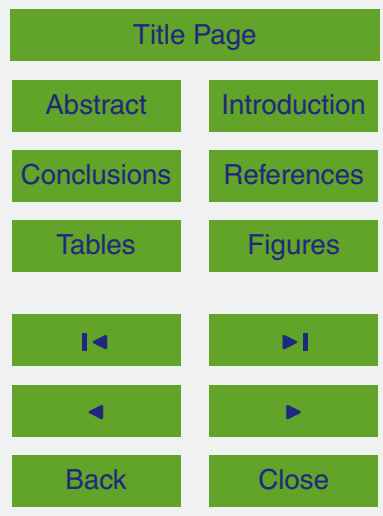

Full Screen / Esc

Printer-friendly Version

Interactive Discussion 
Hoehn, E. and Scholtis, A.: Exchange between a river and groundwater, assessed with hydrochemical data, Hydrol. Earth Syst. Sci., 15, 983-988, doi:10.5194/hess-15-983-2011, 2011.

Jimenez, J., Yañez-Arancibia, A., and Lara-Domínguez, A.: Ambiente, distribución y características estructurales en los manglares del Pacífico de Centro América: contrastes climáticos

5 (Environment, distribution and structural characteristics of mangrove forests in Central America: climatic contrasts), in: Ecosistemas de manglar en América Tropical, 1st ed., edited by: Yañez-Arancibia, A. and Lara-Domínguez, A., Instituto de Ecología, A.C. Centro SEP CONACYT, Mexico, 51-70, 1999.

Jung, M., Burt, T. P., and Bates, P. D.: Toward a conceptual model of floodplain water table response, Water Resour. Res., 40, W12409, doi:10.1029/2003wr002619, 2004.

Kalbus, E., Reinstorf, F., and Schirmer, M.: Measuring methods for groundwater - surface water interactions: a review, Hydrol. Earth Syst. Sci., 10, 873-887, doi:10.5194/hess-10-873-2006, 2006.

Kaser, D. H., Binley, A., Heathwaite, A. L., and Krause, S.: Spatio-temporal variations 15 of hyporheic flow in a riffle-step-pool sequence, Hydrol. Process., 23, 2138-2149, doi:10.1002/hyp.7317, 2009.

Krause, S., Blume, T., and Cassidy, N. J.: Investigating patterns and controls of groundwater up-welling in a lowland river by combining Fibre-optic Distributed Temperature Sensing with observations of vertical hydraulic gradients, Hydrol. Earth Syst. Sci., 16, 1775-1792, doi:10.5194/hess-16-1775-2012, 2012.

Lewandowski, J., Lischeid, G., and Nützmann, G.: Drivers of water level fluctuations and hydrological exchange between groundwater and surface water at the lowland River Spree (Germany): field study and statistical analyses, Hydrol. Process., 23, 2117-2128, doi:10.1002/hyp.7277, 2009.

Loke, M. and Barker, R.: RES2Dinv software, Geotomo Software Company, 2004.

Mendoza, J. A., Ulriksen, P., Picado, F., and Dahlin, T.: Aquifer interactions with a polluted mountain river of Nicaragua, Hydrol. Process., 22, 2264-2273, doi:10.1002/hyp.6822, 2008.

Oxtobee, J. P. A. and Novakowski, K. S.: A field investigation of groundwater/surface water interaction in a fractured bedrock environment, J. Hydrol., 269, 169-193, 2002.

30 Oxtobee, J. P. A. and Novakowski, K. S.: Ground Water/Surface Water Interaction in a Fractured Rock Aquifer, Ground Water, 41, 667-681, doi:10.1111/j.1745-6584.2003.tb02405.x, 2003.

Pinder, G. F. and Sauer, S. P.: Numerical Simulation of Flood Wave Modification Due to Bank Storage Effects, Water Resour. Res., 7, 63-70, doi:10.1029/WR007i001p00063, 1971.

\section{HESSD}

11, 9759-9790, 2014

\section{Investigation of \\ river-aquifer \\ interactions in a \\ tropical coastal area \\ H. Calderon and S. \\ Uhlenbrook}

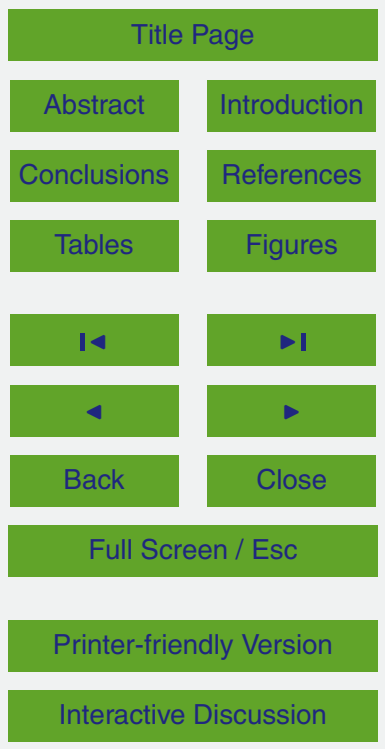


Ruehl, C., Fisher, A. T., Hatch, C., Huertos, M. L., Stemler, G., and Shennan, C.: Differential gauging and tracer tests resolve seepage fluxes in a strongly-losing stream, J. Hydrol., 330, 235-248, doi:10.1016/j.jhydrol.2006.03.025, 2006.

Schaap, M. G., Leij, F. J., and van Genuchten, M. T.: rosetta: a computer program for estimating soil hydraulic parameters with hierarchical pedotransfer functions, J. Hydrol., 251, 163-176, doi:10.1016/S0022-1694(01)00466-8, 2001.

Silliman, S. E. and Booth, D. F.: Analysis of time-series measurements of sediment temperature for identification of gaining vs. losing portions of Juday Creek, Indiana, J. Hydrol., 146, 131148, 1993.

10 Šimůnek, J., van Genuchten, M. T., Gribb, M. M., and Hopmans, J. W.: Parameter estimation of unsaturated soil hydraulic properties from transient flow processes, Soil Till. Res., 47, 27-36, doi:10.1016/S0167-1987(98)00069-5, 1998.

Šimůnek, J., van Genuchten, M. T., and Sejna, M.: The HYDRUS-2-D software package for simulating two-dimensional movement of water, heat, and multiple solutes in variably-saturated media, version 2.0, PC Progress, Prague, 230, 2012.

Sophocleous, M. A.: Stream-floodwave propagation through the Great Bend alluvial aquifer, Kansas: Field measurements and numerical simulations, J. Hydrol., 124, 207-228, doi:10.1016/0022-1694(91)90015-A, 1991.

Sophocleous, M. A.: Interactions between groundwater and surface water: the state of the science, Hydrogeol. J., 10, 52-67, doi:10.1007/s10040-001-0170-8, 2002.

Squillace, P. J.: Observed and Simulated Movement of Bank-Storage Water, Ground Water, 34, 121-134, doi:10.1111/j.1745-6584.1996.tb01872.x, 1996.

Vidon, P.: Towards a better understanding of riparian zone water table response to precipitation: surface water infiltration, hillslope contribution or pressure wave processes?, Hydrol. Process., 26, 3207-3215, doi:10.1002/hyp.8258, 2012.

Welch, C., Cook, P. G., Harrington, G. A., and Robinson, N. I.: Propagation of solutes and pressure into aquifers following river stage rise, Water Resour. Res., 49, 5246-5259, doi:10.1002/wrcr.20408, 2013.

Westhoff, M. C., Savenije, H. H. G., Luxemburg, W. M. J ., Stelling, G. S., van de Giesen, N. $30 \quad$ C., Selker, J. S., Pfister, L., and Uhlenbrook, S.: A distributed stream temperature model using high resolution temperature observations, Hydrol. Earth Syst. Sci., 11, 1469-1480, doi:10.5194/hess-11-1469-2007, 2007.

\section{HESSD}

11, 9759-9790, 2014

\section{Investigation of \\ river-aquifer \\ interactions in a \\ tropical coastal area \\ H. Calderon and S. \\ Uhlenbrook}

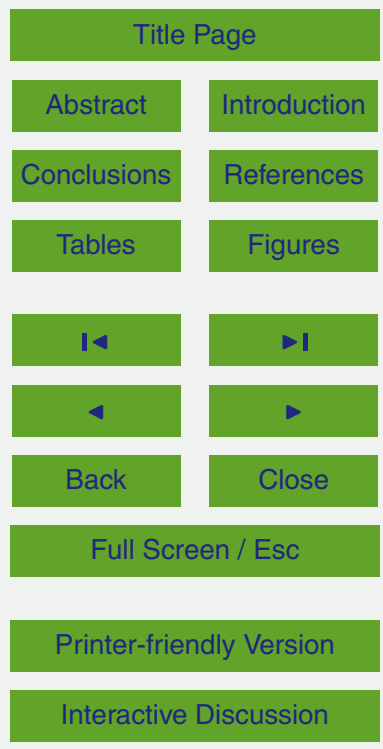


Woessner, W. W.: Stream and Fluvial Plain Ground Water Interactions: Rescaling Hydrogeologic Thought, Ground Water, 38, 423-429, doi:10.1111/j.1745-6584.2000.tb00228.x, 2000.

Wondzell, S. M. and Gooseff, M. N.: Geomorphic controls on hyporheic exchange across scales: watersheds to particles, in: Treatis in Geomorphology, edited by: Shroder, J. F. E., Academic Press, San Diego, 203-218, 2013.

Investigation of river-aquifer

interactions in a tropical coastal area

H. Calderon and S.

Uhlenbrook

\section{Title Page}

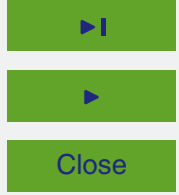


Table 1. Soil hydraulic parameters and optimized $K_{\mathrm{s}}$ values $\left(\mathrm{m} \mathrm{d}^{-1}\right)$ for each material.

\begin{tabular}{lrrrr|rrrr}
\hline & \multicolumn{3}{c}{ Estimated by Rosetta } & \multicolumn{4}{c}{ Optimized Ks values by inverse solution $\left(\mathrm{m} \mathrm{d}^{-1}\right)$} \\
\cline { 2 - 9 } Material & $\theta s(-)$ & $\theta r(-)$ & $\alpha\left(\mathrm{m}^{-1}\right)$ & $n(-)$ & Initial value & Min & Max & Optimized value \\
\hline Clay & 0.39 & 0.1 & 5.9 & 1.48 & 0.3 & 0.3 & 2 & 2 \\
Alluvium & 2.68 & 0.04 & 14.5 & 2.68 & 6 & 5.0 & 12 & 9 \\
Shale & 4.15 & 0.05 & 3.31 & 4.15 & 9 & 5.0 & 13 & 10 \\
\hline
\end{tabular}

\section{HESSD}

11, 9759-9790, 2014

Investigation of river-aquifer

interactions in a tropical coastal area

H. Calderon and S.

Uhlenbrook

Title Page

Abstract

Introduction

Conclusions

References

Tables

Figures

14

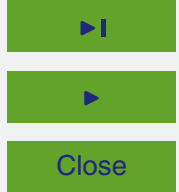

Back

Close

Full Screen / Esc

Printer-friendly Version

Interactive Discussion 
Table 2. Statistical analysis of model performance.

\begin{tabular}{lrrr|rrr}
\hline & \multicolumn{3}{c|}{ Dry period } & \multicolumn{3}{c}{ Rainy period } \\
\cline { 2 - 7 } Observation points & MAE $(\mathrm{m})$ & $R^{2}(-)$ & RMSE $(-)$ & MAE $(\mathrm{m})$ & $R^{2}(-)$ & RMSE $(-)$ \\
\hline P3W & 0.0816 & 0.97 & 0.0822 & 0.3183 & 0.99 & 0.3095 \\
P3W1 & 0.2207 & 0.62 & 0.2307 & 0.8647 & 0.98 & 0.9398 \\
P2W & 0.4679 & 0.92 & 0.4682 & 1.0328 & 0.92 & 1.0638 \\
P1W & 0.1597 & 0.98 & 0.1598 & 0.4849 & 0.95 & 0.4830 \\
P1W1 & 0.1875 & 0.99 & 0.1876 & 0.3023 & 0.95 & 0.3120 \\
P1E1 & 0.2899 & 0.94 & 0.3075 & 0.9170 & 0.91 & 0.9014 \\
P1E & 0.1708 & 0.89 & 0.6218 & 1.2933 & 0.91 & 1.2707 \\
P2E & 0.1880 & 0.93 & 0.2194 & 1.2346 & 0.88 & 1.1916 \\
P3E & 0.0691 & 0.99 & 0.0692 & 0.0572 & 0.95 & 0.0776 \\
\hline
\end{tabular}

\section{HESSD}

11, 9759-9790, 2014

Investigation of river-aquifer

interactions in a tropical coastal area

H. Calderon and S.

Uhlenbrook

Title Page

Abstract

Introduction

Conclusions References

Tables

Figures

14

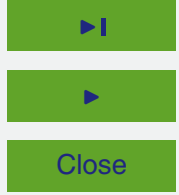

Back

Close

Full Screen / Esc

Printer-friendly Version

Interactive Discussion 

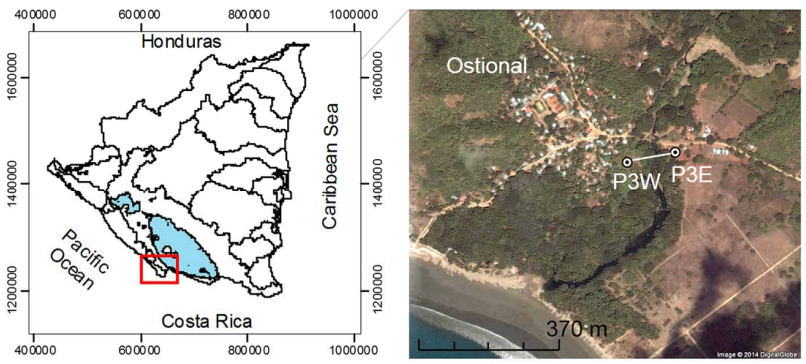

\section{Legend Hydraulic conductivity}

$\square$ Clay $\begin{gathered}\left(m^{-1}\right) \\ 2\end{gathered}$

$\square$ Alluvium 9

$\square$ Shale 10

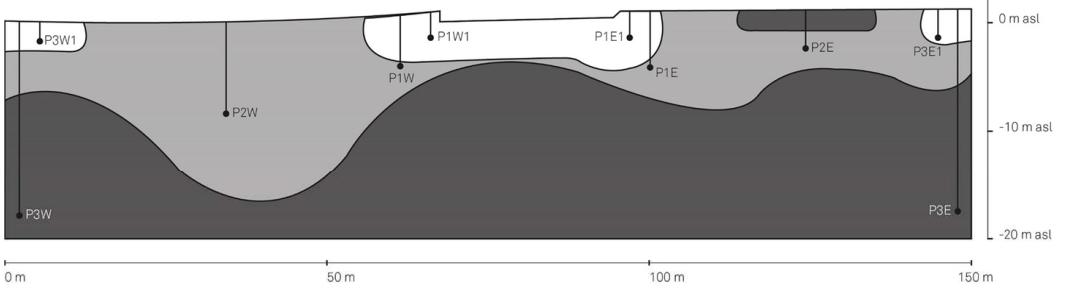

Figure 1. Stratigraphic interpretation at the piezometric cross section based on macro- and micro-analysis of sediment samples (Calderon et al., 2014). Piezometer set up across the river; West (W) and East (E) piezometers, number indicates position with respect to the river banks, 1 is the closest 3 is the farthest from the river. Secondary numbering indicates same location but different depth (i.e. P1E and P1E-1).

\section{HESSD}

11, 9759-9790, 2014

\section{Investigation of river-aquifer \\ interactions in a tropical coastal area \\ H. Calderon and S. \\ Uhlenbrook}

\section{Title Page}

14

Full Screen / Esc

Printer-friendly Version

Interactive Discussion 

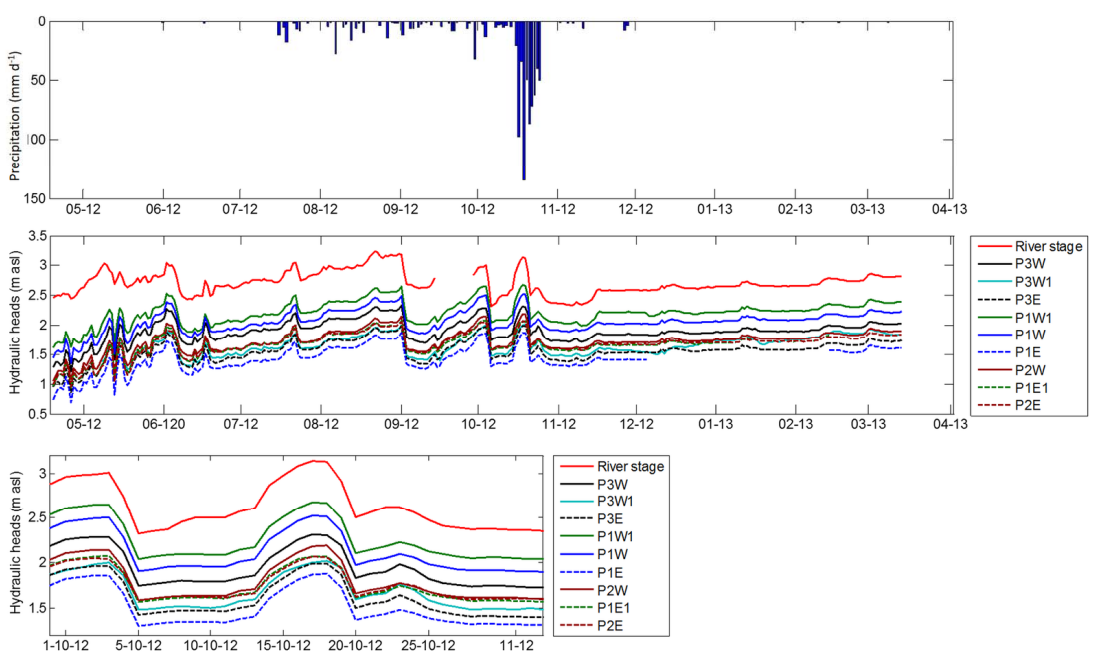

\section{HESSD}

11, 9759-9790, 2014

Investigation of river-aquifer

interactions in a tropical coastal area

H. Calderon and S.

Uhlenbrook

\section{Title Page}

Figure 2. (a) Daily precipitation, (b) mean daily river stage and hydraulic head fluctuations for the period of April 2012 to March 2013, and (c) zoom of river stage and hydraulic head daily average fluctuations for October 2012; locations are given in Fig. 1.

\section{4}

$\triangleleft$

Back

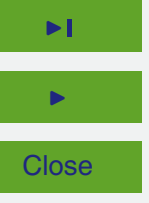

Full Screen / Esc

Printer-friendly Version

Interactive Discussion 
(a)

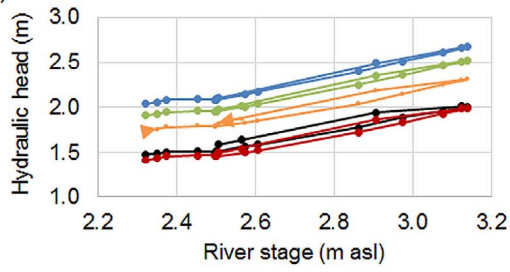

$\rightarrow P 3 W \rightarrow P 3 W 1 \rightarrow P 2 W \rightarrow P 1 W \rightarrow-P 1 W 1$

(c)

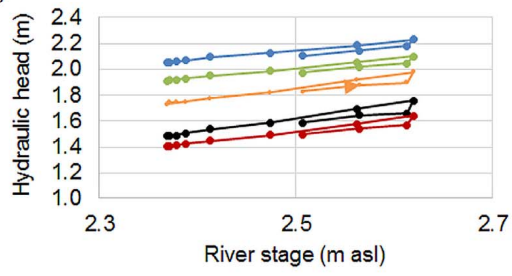

$-\mathrm{P} 3 \mathrm{~W} \rightarrow \mathrm{P} 3 \mathrm{~W} 1 \rightarrow \mathrm{P} 2 \mathrm{~W} \rightarrow \mathrm{P} 1 \mathrm{~W} \rightarrow \mathrm{P} 1 \mathrm{~W} 1$ (b)

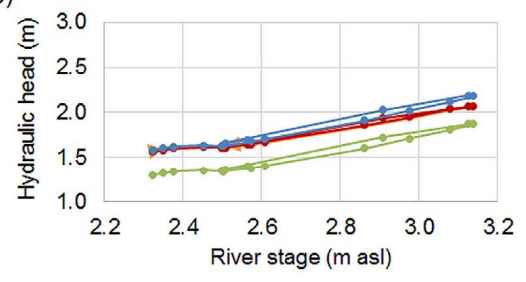

$$
\rightarrow \text { P3E } \rightarrow \text { P2E } \rightarrow \text { P1E } \rightarrow \text { P1E1 }
$$

(d)

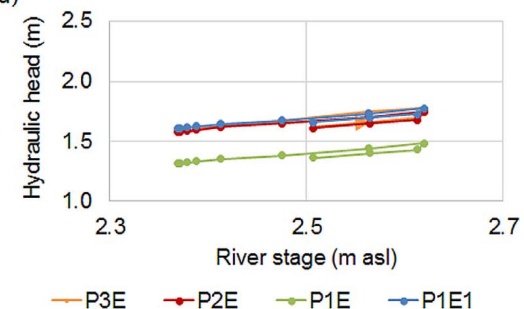

\section{HESSD}

11, 9759-9790, 2014

\section{Investigation of river-aquifer \\ interactions in a tropical coastal area \\ H. Calderon and S. \\ Uhlenbrook}

\section{Title Page}

Abstract

Introduction

Conclusions

References

Tables

Figures

14
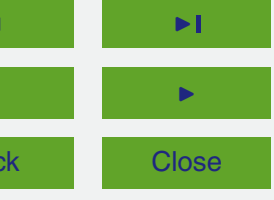

Back

Full Screen / Esc

Printer-friendly Version

Interactive Discussion 

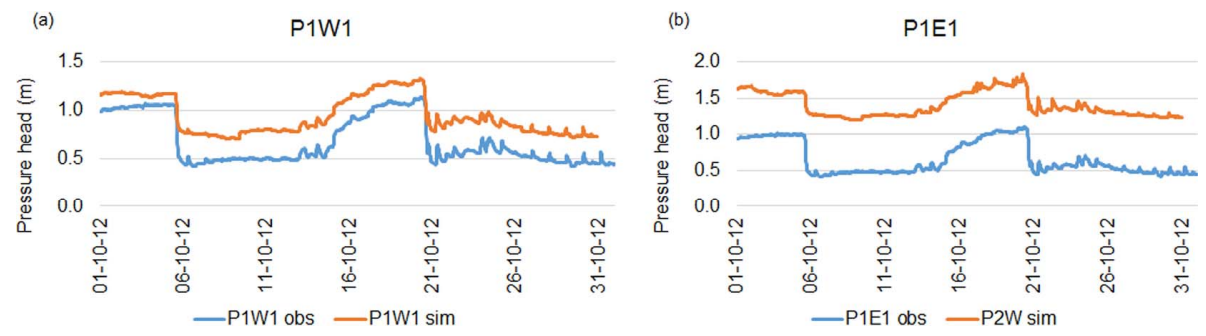

Figure 4. Observed and simulated pressure heads every $30 \mathrm{~min}$ for shallowest piezometers for the period 1-31 October 2012.

\section{HESSD}

11, 9759-9790, 2014

Investigation of river-aquifer

interactions in a tropical coastal area

H. Calderon and S. Uhlenbrook

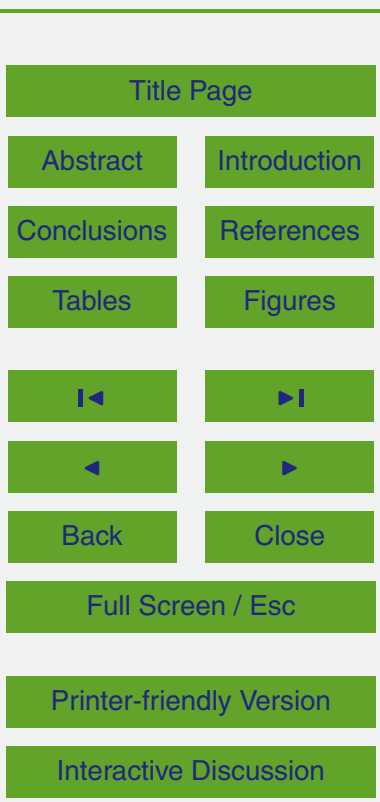



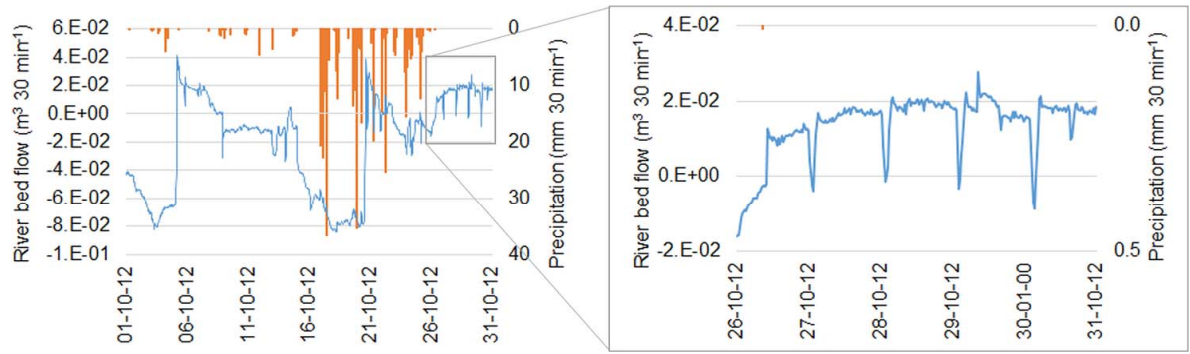

Figure 5. Precipitation and flow across the streambed during October 2012. Negative values indicate groundwater recharge and positive values indicate groundwater exfiltration.

\section{HESSD}

11, 9759-9790, 2014

Investigation of river-aquifer

interactions in a tropical coastal area

H. Calderon and S.

Uhlenbrook

\section{Title Page}

14

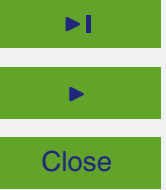

Back

Full Screen / Esc

Printer-friendly Version

Interactive Discussion 

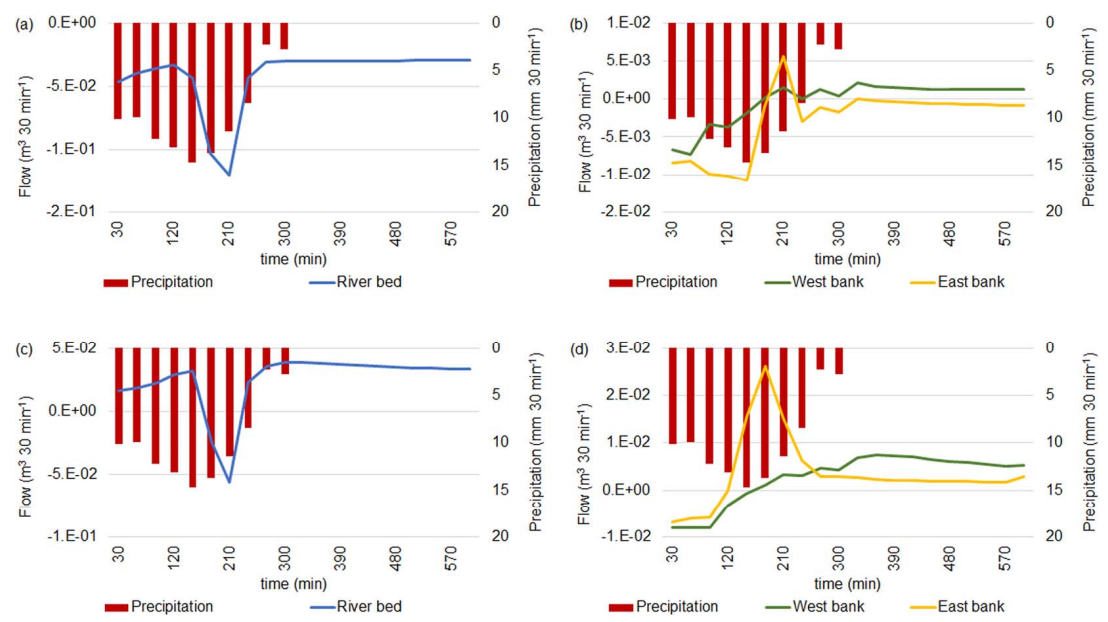

Figure 6. Simulated flow rates for a hypothetical stream stage peak: (a) and (b) dry initial conditions; (c) and (d) wet initial conditions.

\section{HESSD}

11, 9759-9790, 2014

Investigation of river-aquifer

interactions in a tropical coastal area

H. Calderon and S.

Uhlenbrook

Title Page

Abstract

Introduction

Conclusions

References

Tables

Figures

14

Back

Close

Full Screen / Esc

Printer-friendly Version

Interactive Discussion 


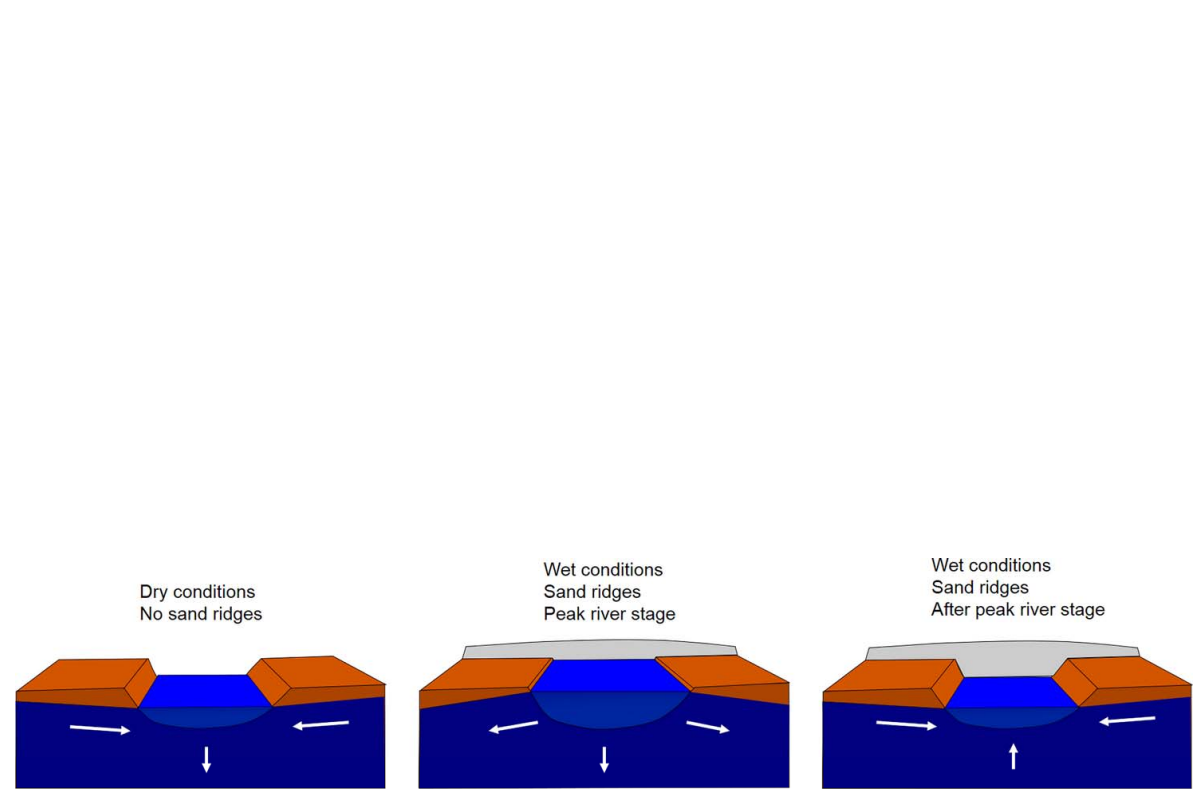

Figure 7. Conceptualization of sand ridges influence on river-aquifer flows.

\section{HESSD}

11, 9759-9790, 2014

Investigation of

river-aquifer

interactions in a

tropical coastal area

H. Calderon and S.

Uhlenbrook

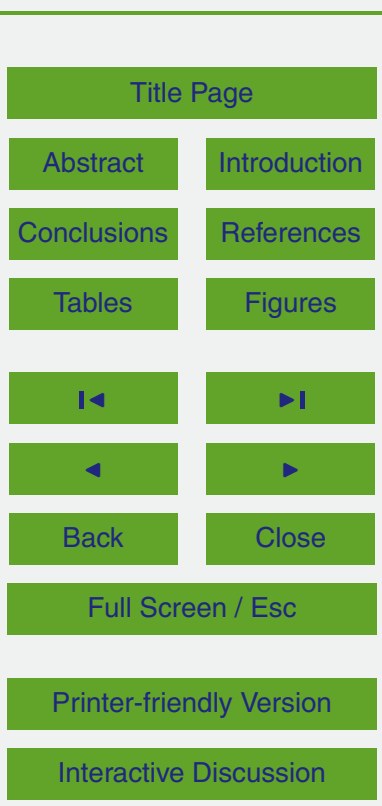

